\title{
Tomato Spotted Wilt Tospovirus Adapts to the TSWV N Gene-Derived Resistance by Genome Reassortment
}

\author{
Wenping Qiu and James W. Moyer
}

First author: Department of Plant Pathology and Microbiology, Texas A\&M University, College Station 77843-2123; and second author: Department of Plant Pathology, North Carolina State University, Raleigh 27695-7616.

Accepted for publication 14 April 1999.

\begin{abstract}
Qiu, W., and Moyer, J. W. 1999. Tomato spotted wilt tospovirus adapts to the TSWV N gene-derived resistance by genome reassortment. Phytopathology 89:575-582.

Pathogen- and host-derived resistance have been shown to suppress infection by many plant viruses. Tomato spotted wilt tospovirus (TSWV) is among these systems; however, it has easily overcome nearly all host resistance genes and has recently been shown to overcome resistance mediated by the TSWV N gene. To better understand the resistance-breaking mechanisms, we have chosen TSWV N gene-derived resistance (TNDR) as a model to study how plant viruses defeat resistance genes. A defined viral population of isolates TSWV-D and TSWV-10, both suppressed by TNDR, was subjected to TNDR selection by serial passage in an N-gene

presence of TNDR selection, but remained as a heterogeneous mixture in the absence of the selection. A genotype assay of 120 local lesion isolates from the first, fourth, and seventh transfers confirmed the shift of genomic composition. Further analysis demonstrated that the individual $\mathrm{L}_{10}, \mathrm{M}_{10}$, and $\mathrm{S}_{\mathrm{D}}$ RNA segments were each selected independently in response to TNDR selection rather than to a mutation or recombination event. Following the seventh transfer on the N-gene transgenic plants, TSWV S RNA remained essentially identical to the S RNA from TSWV-D, indicating that no intermolecular recombination occurred between the two S RNAs from TSWV10 and TSWV-D nor with the transferred $\mathrm{N}$ gene. These results support the hypothesis that TSWV utilizes genome reassortment to adapt to new host genotypes rapidly and that elements from two or more segments of the genome are involved in suppression of the resistance reaction.
\end{abstract} transgenic plant. The genotype analysis demonstrated that the mixed viral population was driven to form a specific reassortant, $\mathrm{L}_{10} \mathrm{M}_{10} \mathrm{~S}_{\mathrm{D}}$, in the

Tomato spotted wilt tospovirus (TSWV), the type member of the genus Tospovirus in the family Bunyaviridae, has a broad host range covering more than 600 plant species in both monocots and dicots (20). In addition to the large number of natural hosts, it also has been shown that TSWV easily defeats resistance genes and rapidly adapts to the resistant hosts $(17,18,41)$. For example, a tomato line with the $S w^{5}$ resistance gene initially conferred resistance to at least five TSWV isolates (49), but recently was observed to be susceptible to a virulent TSWV isolate (7). It is generally accepted that TSWV exists in nature as a heterogeneous population of stable isolates $(5,9,10,37,48,51 ; \mathrm{J}$. W. Moyer, unpublished data) that may serve as the genetic reservoir for adaptation. However, the underlying genetic mechanisms for the adaptation of TSWV as well as other viruses within the family Bunyaviridae to different hosts are poorly understood $(5,14,20)$.

The TSWV genome is distributed on three single-stranded RNA molecules designated as L RNA, M RNA, and S RNA. The L RNA encodes a putative RNA-dependent RNA polymerase (RdRp) in the viral complementary-sense RNA (12). RdRp purified from virions has been shown to synthesize short, double-stranded viral RNAs in vitro, implying that the TSWV virion packages the functional RNA polymerase (2). The M RNA encodes a nonstructural protein (NSm) in the viral-sense RNA and a G1/G2 precursor to two glycoproteins in viral complementary-sense RNA $(28,30)$. The G1/G2 precursor autocatalytically processes to the individual G1 and G2 proteins found in the viral envelope (1). The NSm protein is closely associated with tubular structures in plant and insect cells transiently expressing the NSm protein, suggesting its association with cell-to-cell movement of TSWV (50). The S RNA encodes two pro-

Corresponding author: J. W. Moyer; E-mail address: james_moyer@ncsu.edu

Publication no. P-1999-0524-02R

(C) 1999 The American Phytopathological Society
Additional keywords: genomic marker.

teins, a nonstructural protein (NSs) in the viral-sense RNA to which no biological function has yet been assigned and the nucleocapsid protein $(\mathrm{N})$ in the viral complementary-sense RNA with a role of packaging viral genomic RNAs (13). In addition, both the M RNA and S RNA possess the characteristic A-U-rich intergenic regions (IGR) $(13,30)$.

Transgenic plants transformed with the TSWV N gene vary in their degree of resistance to different TSWV isolates (8,22), which is defined as TSWV N gene-derived resistance (TNDR). In most cases, TNDR was assessed against homologous or closely related TSWV isolates. While some transgenic lines were resistant to closely related TSWV isolates, others were resistant to species other than TSWV $(38,52)$. TNDR was postulated to be either RNA mediated or protein mediated $(11,21,27,33,39,40,43,52)$. Recent evidence suggests that posttranscriptional transgene silencing may be involved in the transinactivation of an invading TSWV viral genome of a specific strain $(39,40)$. Despite the wealth of information about the effect of TNDR on individual isolates, little is known about how TNDR impacts the TSWV population consisting of various isolates.

In a previous study (44), a reassortant, $\mathrm{L}_{10} \mathrm{M}_{10} \mathrm{~S}_{\mathrm{D}}$, was isolated from a mixed infection of two isolates, TSWV-D and TSWV-10, on the susceptible plant Nicotiana tabacum cv. Burley 21. TSWV$\mathrm{D}$ and TSWV-10 were suppressed by TNDR, but the reassortant $\mathrm{L}_{10} \mathrm{M}_{10} \mathrm{~S}_{\mathrm{D}}$ was able to overcome TNDR, although it was isolated from susceptible plants. This observation prompted us to evaluate if TNDR could exert a specific selection pressure on the viral population composed of the two suppressed isolates to direct the formation of a specific reassortant or reassortants. To test this hypothesis, a mixed viral population of the two suppressed isolates, TSWV-D and TSWV-10, was subjected to seven parallel passages on the susceptible and TSWV N-gene transgenic plants. The TSWV genome composition shift of the viral population was monitored with the isolate-specific reverse-transcription polymerase chain reaction (RT- 
PCR) genomic markers (44). The genotypes of 120 local lesion isolates selected from the first, fourth, and seventh passages on both hosts were also assayed as additional evidence for the genome composition shift. The results showed that viral RNA segments from a mixed TSWV population are able to reassort in an appropriate combination that facilitates adaptation to new host plants.

\section{MATERIALS AND METHODS}

TSWV isolates and host plants. TSWV-D was isolated from dahlia (Dahlia hybrida) originating in the Netherlands, and TSWV-10 was isolated from peanut (Arachis hypogaea) in the United States. Stock cultures of both isolates were stored as frozen leaves at $-80^{\circ} \mathrm{C}$, and working cultures were recovered on $N$. benthamiana and maintained on Emilia sonchifolia or N. benthamiana.

Resistant plants were selected from N. tabacum cv. Burley 21 transformed by the binary vector carrying the TSWV N gene from TSWV-D (42). Resistance was expressed as a reduction in local lesion number and no systemic movement beyond the inoculated leaves. $\mathrm{R}_{4}$ plants were used in all experiments. All experiments were conducted in a greenhouse at 25 to $28^{\circ} \mathrm{C}$.

Constitutive or induced TNDR. Susceptible and N-gene transgenic $N$. tabacum cv. Burley 21 at the three-leaf stage were first inoculated with TSWV-D- or TSWV-10-infected leaf tissue from $N$. benthamiana $(1: 5, \mathrm{wt} / \mathrm{vol})$ in the inoculation buffer $(10 \mathrm{mM}$ Tris$\mathrm{HCl}, \mathrm{pH} 7.8 ; 10 \mathrm{mM} \mathrm{Na} \mathrm{SO}_{3}$; and $0.1 \%$ cysteine-HCl). Two weeks postinoculation when plants were at the six-leaf stage, the second and third leaves numbered from the top were challenge-inoculated with TSWV-D, TSWV-10, and the three reassortants. Symptoms on upper noninoculated leaves were recorded 18 days after the challenge inoculation. Five plants were inoculated per treatment in two replicated experiments.

Serial passages to exert the selection on the viral population. The symptomatic leaves of $N$. benthamiana infected by TSWV-D or TSWV-10 were ground in cold inoculation buffer at 1:5 (wt/vol). The serially diluted inocula made from systemically infected $N$. benthamiana leaves by TSWV-D or TSWV-10 were inoculated on
$\mathbf{L}$

$\begin{array}{lll}\text { D } & \text { R } 10\end{array}$

A

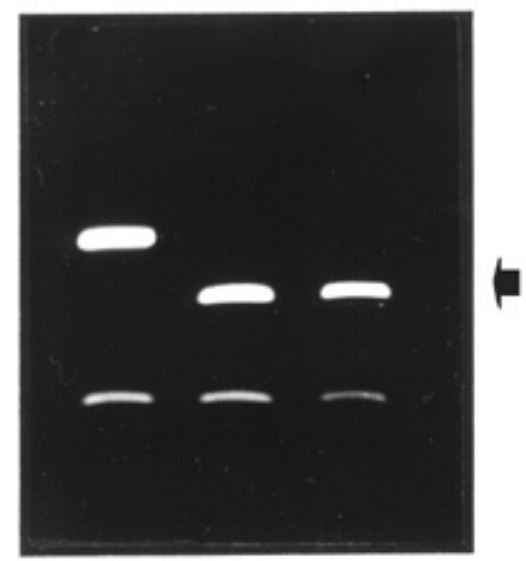

B
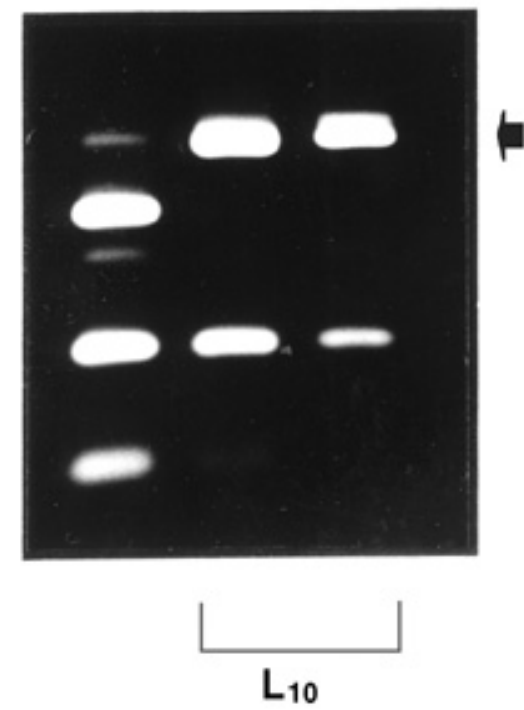

M

D $\quad \mathrm{R} \quad 10$
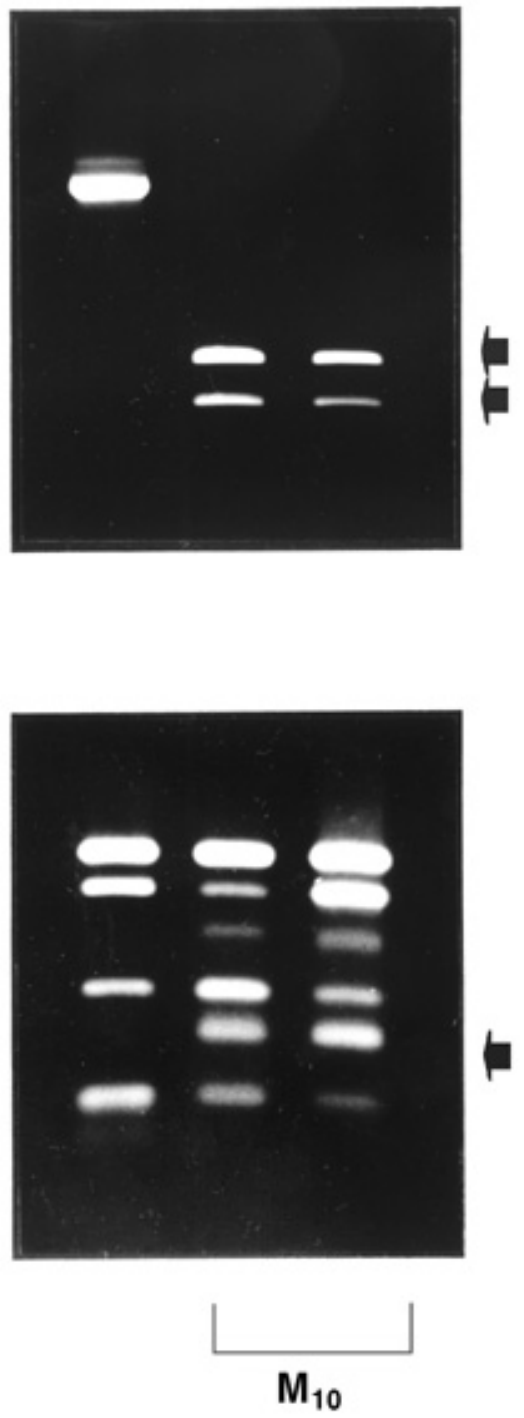

S
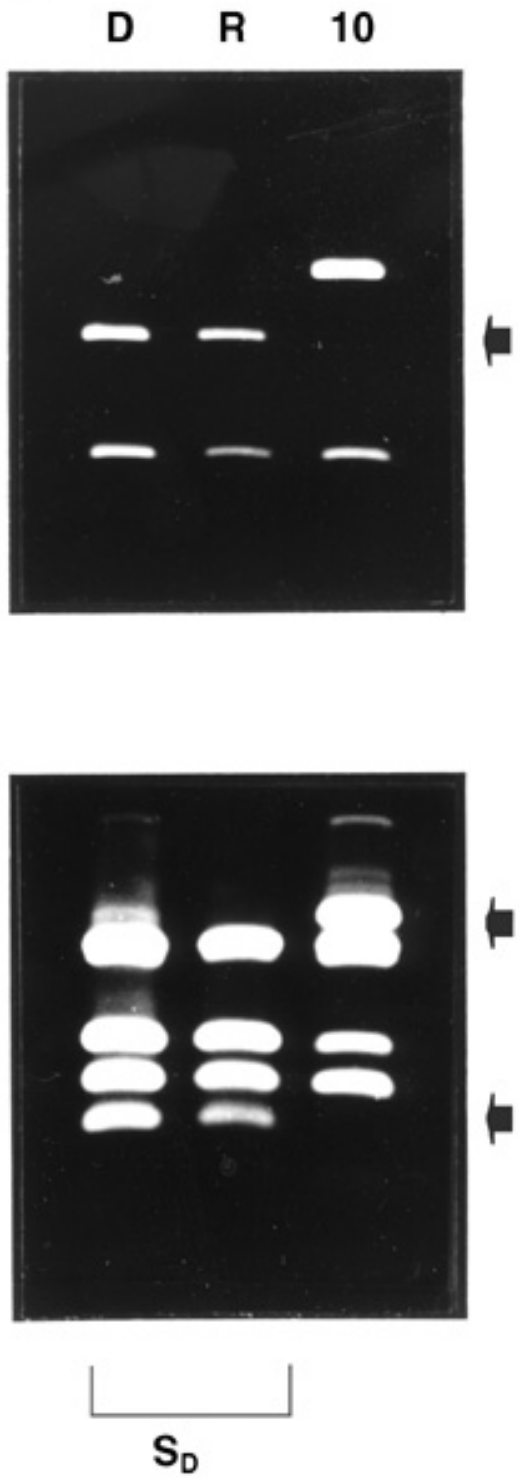

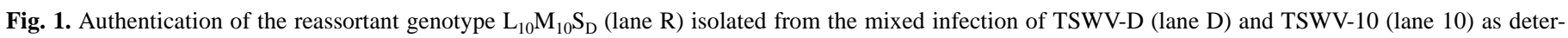

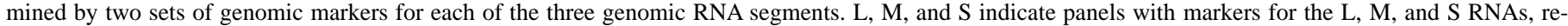

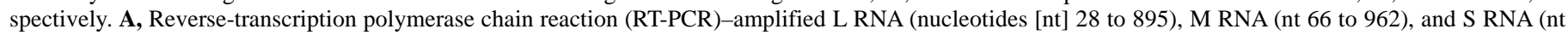

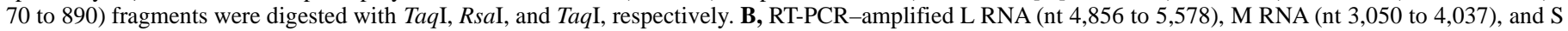
RNA (nt 1,983 to 2,767) fragments were digested with AluI. Arrows on the right indicated the signature restriction fragments for $\mathrm{L}_{10}$, $\mathrm{M}_{10}$, and $\mathrm{S}_{\mathrm{D}}$. 
cucumber (Cucumis sativus cv. National Pickling) cotyledons to determine the relative viral concentration. Statistical analysis of local lesion numbers showed that the viral concentration used in the coinoculation was similar for both isolates. The mixed inocula were prepared by mixing equal volumes of each inoculum followed by application to susceptible and N-gene transgenic $N$. tabacum cv. Burley 21 leaves predusted with Carborundum. Inoculum for subsequent serial transfers was prepared from systemically infected tissue of the previous passage on susceptible and $\mathrm{N}$-gene transgenic $N$. tabacum cv. Burley 21. The viral cultures were passed and collected through seven serial transfers. At each passage, $N$. benthamiana was also inoculated. Total RNA was extracted from $N$. benthamiana to determine the presence of genome segments from each parent as described below. A reference stock of systemically infected susceptible and $\mathrm{N}$-gene transgenic $N$. tabacum $\mathrm{cv}$. Burley 21 leaves from each transfer was also stored at $-80^{\circ} \mathrm{C}$ for the subsequent local lesion assay.

Systemically infected tissue from each transfer was inoculated on susceptible N. tabacum cv. Burley 21 leaves for lesion production. Twenty local lesion isolates were obtained from the first, fourth, and seventh transfers of systemically infected susceptible and Ngene transgenic $N$. tabacum cv. Burley 21. Individual lesions were excised and ground in $200 \mu \mathrm{l}$ of inoculation buffer and inoculated onto $N$. benthamiana. The genotype of each local lesion isolate was determined for 20 local lesion isolates derived from three (first, fourth, and seventh) serial transfers on both lines.

Verification of parental origin of genome segment. Total plant RNA was extracted from $100 \mathrm{mg}$ of TSWV-infected $N$. benthamiana leaves using RNA ISOLATER (Genosys Biotechnologies, Inc., The Woodlands, TX) according to the supplier's protocols. First-strand cDNA synthesis, RT-PCR, and restriction enzyme digestion were performed according to the methods previously described (44). The RT-PCR products were purified by Qiagen PCR purification columns (Qiagen, Inc., Chatsworth, CA). Amplified L RNA (nucleotides [nt] 4,856 to 5,578), M RNA (nt 3,050 to 4,037), and S RNA (nt 1,983 to 2,767) fragments were subjected to AluI digestion. Amplified fragments from nt 28 to 895 of the L RNA and from nt 70 to 890 of the S RNA were digested by TaqI. The fragment from nt 66 to 962 of the M RNA was subjected to RsaI digestion. Digested products were resolved on a $1.5 \%$ agarose gel and stained by ethidium bromide for characterization of the TSWV$\mathrm{D}$ and TSWV-10 genotypes.

Cloning and sequencing strategy. TSWV virion purification and virion RNA extractions were performed as previously described $(29,35)$. Sequence of the $5^{\prime}$ and $3^{\prime}$ termini of the viral RNA was determined by the method of Weng and Xiong (54). The remainder of the S RNA sequence was determined from RT-PCR products. The N gene was amplified from primers S2767 (5' GCTCTAGAGCCATCATGTCTAAGGTTAAGCTCAC 3'; restriction enzyme site underlined, number denotes the position of the primer in the viralsense strand) and S1983 (5' CCCTCGAGGCTTTCAAGCAAGTTCTGCG $\left.3^{\prime}\right)$. The intergenic region was amplified with primers S2083 (5' GGAAGTATTGCTATGG 3') and S1282 (5' CACTTGAATGTCTTCC $\left.3^{\prime}\right)$. The NSs gene was amplified with primers S1507 (5' CCGGACACAGCAAGATTA 3') and S70 (5' CACAGTACCAATAACC 3').

The RT-PCR-amplified products were cloned into pGEM-T vectors (Promega Corp., Madison, WI). The recombinant plasmids were purified by the WizardPlus Minipreps DNA Purification System (Promega Corp.). The cDNA clones were sequenced by the dideoxynucleotide chain termination method (46) using Sequenase 2.0 (United States Biochemical Corp., Cleveland). The sequences of the NSs open reading frame (ORF) from reassortant $\mathrm{L}_{10} \mathrm{M}_{10} \mathrm{~S}_{\mathrm{D}}$ isolated from the susceptible and seventh-transferred viral populations on $\mathrm{N}$-gene transgenic plants and $\mathrm{L}_{10+\mathrm{D}} \mathrm{M}_{10} \mathrm{~S}_{\mathrm{D}}$ isolated from the seventh-transferred viral population on susceptible plants were determined by the DNA Sequencing Core Laboratory, University of Florida (Gainesville).

\section{RESULTS}

Characterization of the TNDR-breaking reassortant. The TNDR-breaking reassortant, $\mathrm{L}_{10} \mathrm{M}_{10} \mathrm{~S}_{\mathrm{D}}$, was originally obtained from susceptible $N$. tabacum cv. Burley 21 and assayed on several hosts including $\mathrm{N}$-gene transgenic $N$. tabacum cv. Burley 21 that was transformed by the TSWV N gene (42). The same TSWV genotype was isolated from two additional experiments conducted on susceptible plants. Isolates obtained from each experiment included the parental isolates and two other reassortants in addition to $\mathrm{L}_{10} \mathrm{M}_{10} \mathrm{~S}_{\mathrm{D}}$. Only $\mathrm{L}_{10} \mathrm{M}_{10} \mathrm{~S}_{\mathrm{D}}$ was capable of sustaining a systemic invasion of the plants displaying TNDR. The parental and other reassortant genotypes caused local lesions but no systemic invasion on the $\mathrm{N}$-gene transgenic plants.

The genotype of the TNDR-breaking reassortant was validated by the genomic markers to confirm that the L and M RNAs were derived from TSWV-10 and the S RNA was from TSWV-D. The genotype was first defined by the genomic markers in the amplified L RNA (nt 4,856 to 5,578), M RNA (nt 3,050 to 4,037), and S RNA (nt 1,983 to 2,767) fragments (Fig. 1A) and was further authenticated by the second set of genomic markers in the regions of the L RNA (nt 28 to 895), M RNA (nt 66 to 962), and S RNA (nt 70 to 890) fragments (Fig. 1B). This result additionally demonstrated that no large intermolecular recombination had occurred resulting in an exchange of two major portions of the L RNA nor of the two ORFs on the M and S RNAs.

The constitutive expression of TNDR. The TNDR phenotype is characterized by plants that express local lesions induced by TSWV-D and TSWV-10, albeit to a lesser extent than on susceptible plants, but systemic invasion is inhibited. To gain further insight into the nature of TNDR, experiments were conducted to determine if the ability to overcome TNDR was due either to overcoming a constitutively expressed resistance or to a failure to initiate an interaction induced by the viruses. The TNDR plants were inoculated with TSWV-D and TSWV-10 and then challenged 14 days

TABLE 1. The phenotypes of parental and reassortant isolates on resistant (N-gene transgenic) and susceptible Nicotiana tabacum cv. Burley 21 to determine if the resistance is inducible or constitutively expressed

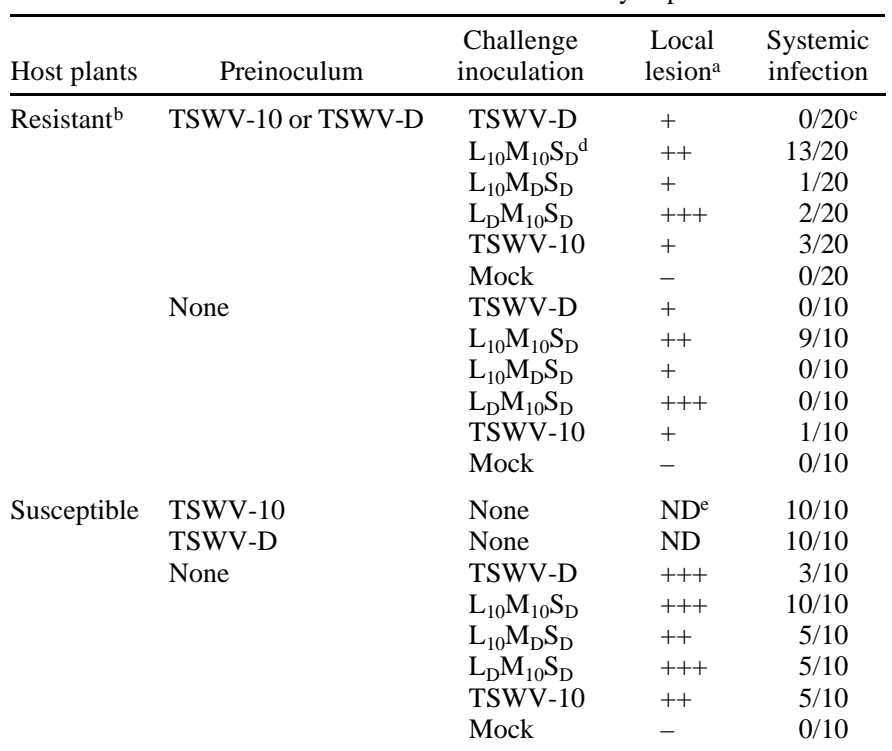

a The number of local lesions per leaf was measured by averaging the lesion number counted in a $20-\mathrm{cm}^{2}$ leaf area of 10 leaves. The lesion number was categorized into three classes: $+=1$ to $10 ;++=11$ to 50 ; and $+++=$ over 50 .

b Resistant: Tomato spotted wilt virus (TSWV) N gene-derived resistant $N$. tabacum cv. Burley 21. Susceptible: N. tabacum cv. Burley 21.

${ }^{c}$ Data were combined from the preinoculation treatments with the two suppressed isolates.

d Subscript refers to the viral origin (isolate) of that segment: TSWV-D or TSWV-10.

e Not determined. 
later with the TNDR-breaking reassortant, $\mathrm{L}_{10} \mathrm{M}_{10} \mathrm{~S}_{\mathrm{D}}$, two other reassortants, $\mathrm{L}_{10} \mathrm{M}_{\mathrm{D}} \mathrm{S}_{\mathrm{D}}$ and $\mathrm{L}_{\mathrm{D}} \mathrm{M}_{10} \mathrm{~S}_{\mathrm{D}}$, as well as the two suppressed parental isolates, TSWV-D and TSWV-10. Thirteen of twenty plants preinoculated with the suppressed isolates and subsequently challenged with the TNDR-breaking reassortant $\mathrm{L}_{10} \mathrm{M}_{10} \mathrm{~S}_{\mathrm{D}}$ were systemically infected. Nine of ten mock-inoculated plants expressed systemic symptoms when challenged with $\mathrm{L}_{10} \mathrm{M}_{10} \mathrm{~S}_{\mathrm{D}}$. Seventeen of twenty plants displayed only local infections when the preinoculated plants were challenged with the reassortants $\mathrm{L}_{10} \mathrm{M}_{\mathrm{D}} \mathrm{S}_{\mathrm{D}}$ and $\mathrm{L}_{\mathrm{D}} \mathrm{M}_{10} \mathrm{~S}_{\mathrm{D}}$ or the two suppressed parental isolates. Reassortant $\mathrm{L}_{\mathrm{D}} \mathrm{M}_{10} \mathrm{~S}_{\mathrm{D}}$ generated the largest number of local lesions on the inoculated leaves but was unable to systemically infect the $\mathrm{N}$-gene transgenic plants. The two parental isolates and all three reassortants were able to systemically infected susceptible $N$. tabacum cv. Burley 21 (Table 1). These results demonstrated that the ability of the reas- sortant $\mathrm{L}_{10} \mathrm{M}_{10} \mathrm{~S}_{\mathrm{D}}$ to overcome TNDR is not due to a failure to trigger the resistance reaction in the host; thus, TNDR is constitutively expressed.

The effect of TNDR on the genomic composition of a mixed viral population. To determine if TNDR could impose a selection pressure that would alter the genomic composition of the TSWV viral population, mixed infections of TSWV-D and TSWV-10 were analyzed at comparable intervals through serial passages on either susceptible or $\mathrm{N}$-gene transgenic plants. The origin of the genomic RNA segments was determined following each passage. The L RNAs from both TSWV-D and TSWV-10 coexisted in the viral population from the first to the seventh passage on susceptible plants. However, the L RNA from TSWV-10 became the dominant genomic segment following the fifth transfer on the N-gene transgenic plants (Fig. 2, panel L). The M RNA from TSWV-10 was
A

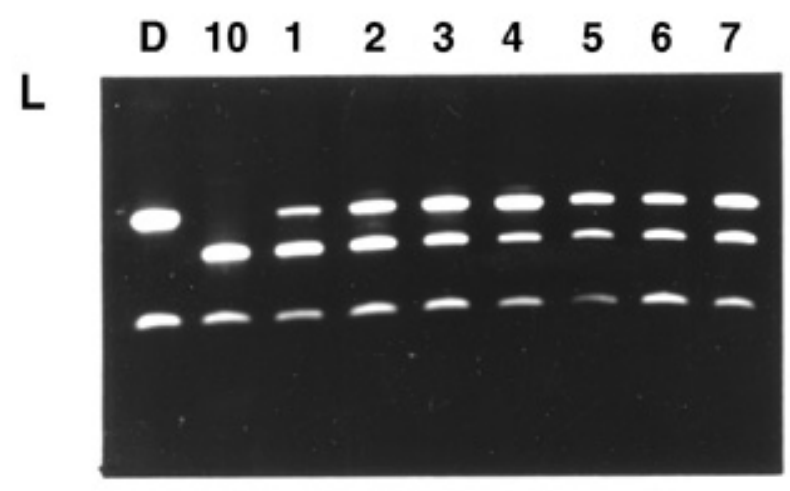

M

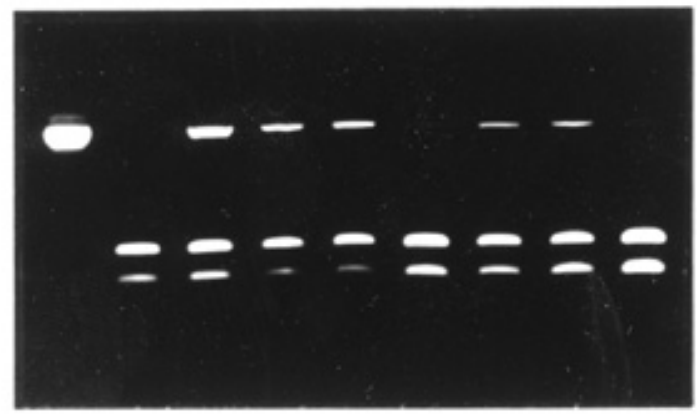

S

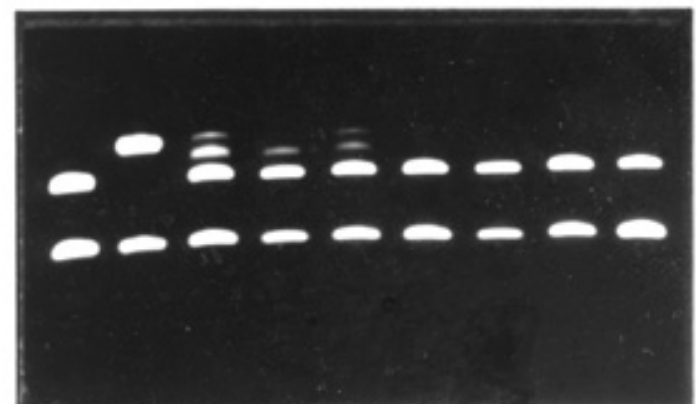

B
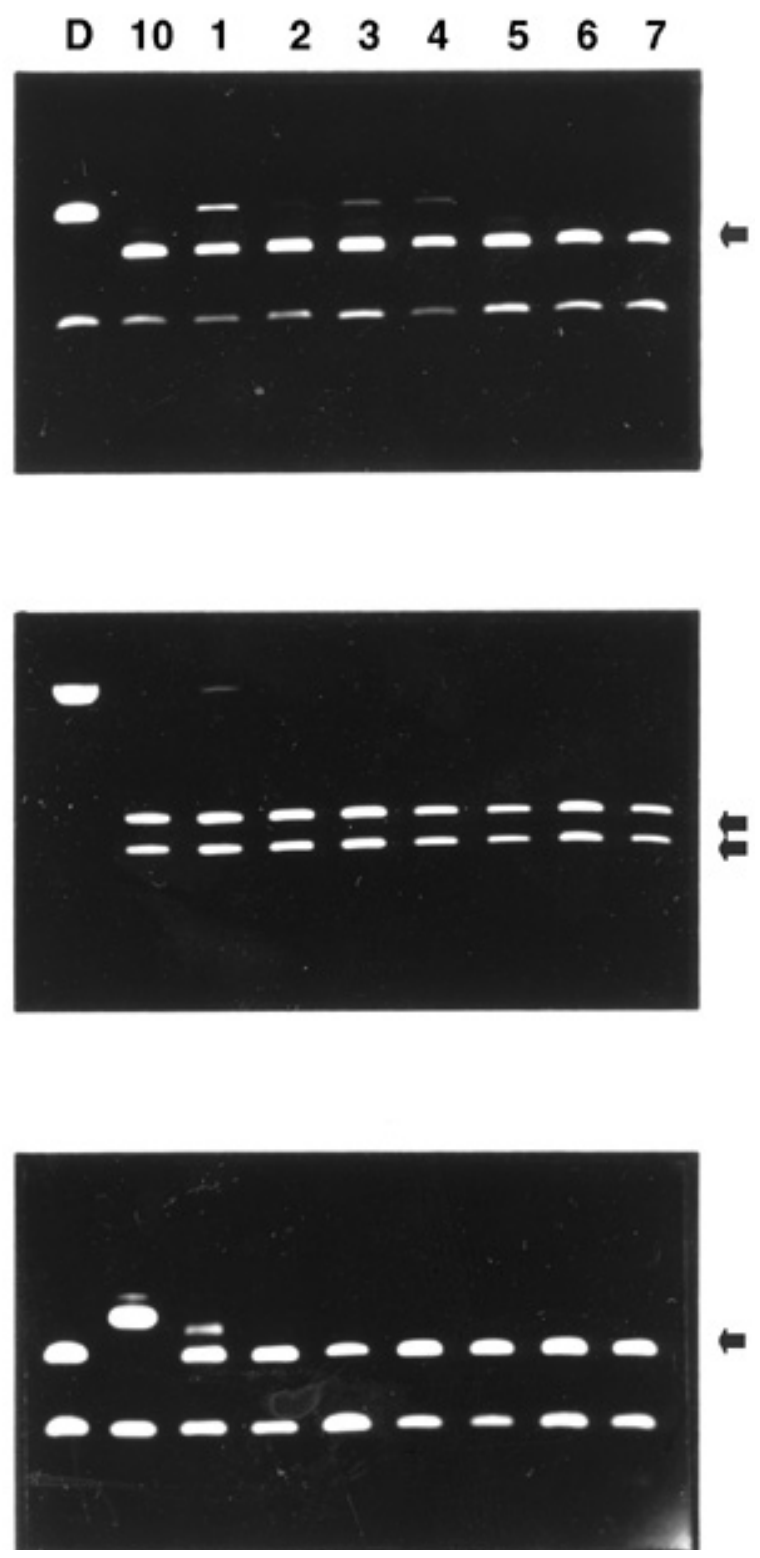

Fig. 2. The viral genomic composition shift in a mixed viral infection of TSWV-D and TSWV-10 during seven serial passages on the susceptible Nicotiana tabacum cv. Burley 21 and the TSWV N gene-derived resistance (TNDR) N. tabacum cv. Burley 21. A, Mixed tomato spotted wilt virus (TSWV) infection on the susceptible $N$. tabacum cv. Burley 21. B, Mixed TSWV infection on the TNDR N. tabacum cv. Burley 21. L, Reverse-transcription polymerase chain reaction (RT-PCR)-amplified L RNA (nucleotides [nt] 28 to 895) fragment digested by TaqI; M, amplified M RNA (nt 66 to 962 ) fragment digested by RsaI; and S, amplified S RNA (nt 70 to 890) fragment digested by TaqI. Lanes D and 10 contain the reference markers for three genomic segments from the two parental isolates, TSWV-D and TSWV-10. Lanes 1 to 7 indicates the seven serial passages. Arrows on the right indicated the signature restriction fragments for $\mathrm{L}_{10}, \mathrm{M}_{10}$, and $\mathrm{S}_{\mathrm{D}}$. 
dominant, although the M RNA from TSWV-D could be detected following the seventh transfer on susceptible plants. In contrast, the M RNA from TSWV-D was below the limit of detection by the third transfer on the $\mathrm{N}$-gene transgenic plants (Fig. 2, panel M). Unlike the L and M RNAs, the S RNA from TSWV-10 was less competitive (44) and could not be detected on either susceptible or $\mathrm{N}$-gene transgenic plants following the fourth and third transfers, respectively (Fig. 2, panel $\mathrm{S}$ ).

The viral genome segment composition detected in total RNA extracts were confirmed by analyzing 20 local lesion isolates selected randomly from each of the first, fourth, and seventh transfers of the mixed viral population on both susceptible and $\mathrm{N}$-gene transgenic plants (Table 2). The genomic makeup of each of the 20 local lesion isolates from the seventh transfer of the mixed viral population passed through the $\mathrm{N}$-gene transgenic plants was $\mathrm{L}_{10} \mathrm{M}_{10} \mathrm{~S}_{\mathrm{D}}$. This genotype was obtained in 5 of 20 local lesion isolates in the first transfer and 8 of 20 local lesion isolates after the fourth transfer on the $\mathrm{N}$-gene transgenic plants.

In contrast, 14 of 20 local lesion isolates from the seventh transfer of the population passed through susceptible plants were $\mathrm{L}_{10+\mathrm{D}} \mathrm{M}_{10} \mathrm{~S}_{\mathrm{D}}$. The same genotype was detected in 7 of 20 local lesion isolates in the first transfer and 10 of 20 local lesion isolates in the fourth transfer on susceptible plants (Table 2).

The impact of TNDR on the S RNA. We previously demonstrated that the S RNA from TSWV-D has a competitive advantage over the S RNA from TSWV-10 on susceptible hosts and that the competitiveness is associated with the absence of a 33-nt duplicate sequence in the IGR (44). Here, we examined the entire S RNA to determine if the observed changes were specifically related to the adaptation to a resistant host. After seven passages of the mixed viral population through the $\mathrm{N}$-gene transgenic plants, the S RNA in the viral population was contributed solely by the TSWV-D isolate. The entire S RNA of reassortant $\mathrm{L}_{10} \mathrm{M}_{10} \mathrm{~S}_{\mathrm{D}}$ (designated as $\mathrm{L}_{10} \mathrm{M}_{10} \mathrm{~S}_{\mathrm{D}}$-TB-7 reassortant), which was isolated following the seventh transfer on the $\mathrm{N}$-gene transgenic plants, was sequenced and compared with the S RNAs from the two parental isolates, TSWV-D (GenBank accession no. AF020660) and TSWV10 (GenBank accession no. AF020559). The S RNA of $\mathrm{L}_{10} \mathrm{M}_{10} \mathrm{~S}_{\mathrm{D}^{-}}$ TB-7, although of identical length (2,955 nt), was similar but not identical to the S RNA from TSWV-D. The nucleotide sequence comparison revealed that $\mathrm{C}_{51}$ of the S RNA from TSWV-D was substituted with $U$ in the $5^{\prime}$ untranslated region (UTR) and $\mathrm{G}_{1712}$ was substituted with $A$ in the IGR of $\mathrm{L}_{10} \mathrm{M}_{10} \mathrm{~S}_{\mathrm{D}^{-}}$TB-7. The IGR of $\mathrm{L}_{10} \mathrm{M}_{10} \mathrm{~S}_{\mathrm{D}^{-}}$ TB-7 had 535 nt analogous to that of the S RNA from TSWV-D. Both the $3^{\prime}$ UTR and N ORF of the S RNA from reassortant $\mathrm{L}_{10} \mathrm{M}_{10} \mathrm{~S}_{\mathrm{D}}$-TB-7 were identical to those of the S RNA from TSWV-D.

The NSs ORF was the most variable between the two S RNAs from TSWV-D and reassortant $\mathrm{L}_{10} \mathrm{M}_{10} \mathrm{~S}_{\mathrm{D}}$-TB-7. Substitutions in the NSs ORF in the S RNA from TSWV-D following seven passages through the $\mathrm{N}$-gene transgenic plants occurred in the following locations: $\mathrm{N}_{158}$ to $\mathrm{D}, \mathrm{P}_{233}$ to $\mathrm{S}, \mathrm{I}_{311}$ to $\mathrm{T}, \mathrm{V}_{370}$ to $\mathrm{E}, \mathrm{R}_{408}$ to $\mathrm{Q}$, and $\mathrm{R}_{450}$ to $\mathrm{G}$. To determine the linkage of those substitutions with the adaptation of TSWV-D S RNA to the N-gene transgenic plants, the NSs ORFs were sequenced in the reassortant $\mathrm{L}_{10} \mathrm{M}_{10} \mathrm{~S}_{\mathrm{D}}$ previously isolated from susceptible hosts and from an isolate with the mixed genotype $L_{10+D} M_{10} S_{D}$ (designated as $L_{10+D} M_{10} S_{D}-B-7$ ) following seven transfers through susceptible plants. The four amino acid substitutions of $\mathrm{P}_{233}$ to $\mathrm{S}, \mathrm{V}_{370}$ to $\mathrm{E}, \mathrm{R}_{408}$ to $\mathrm{Q}$, and $\mathrm{R}_{450}$ to $\mathrm{G}$ occurred in the NSs ORFs of $\mathrm{L}_{10} \mathrm{M}_{10} \mathrm{~S}_{\mathrm{D}}-\mathrm{TB}-7, \mathrm{~L}_{10+\mathrm{D}} \mathrm{M}_{10} \mathrm{~S}_{\mathrm{D}}-\mathrm{B}-7, \mathrm{~L}_{10} \mathrm{M}_{10} \mathrm{~S}_{\mathrm{D}}$, and TSWV-10 S RNA. $\mathrm{T}_{311}$ was conserved in the NSs ORFs from $\mathrm{L}_{10} \mathrm{M}_{10} \mathrm{~S}_{\mathrm{D}}-\mathrm{TB}-7, \mathrm{~L}_{10+\mathrm{D}} \mathrm{M}_{10} \mathrm{~S}_{\mathrm{D}}-\mathrm{B}-7$, and $\mathrm{L}_{10} \mathrm{M}_{10} \mathrm{~S}_{\mathrm{D}}$. $\mathrm{D}_{158}$ was unique to the NSs ORF of $\mathrm{L}_{10} \mathrm{M}_{10} \mathrm{~S}_{\mathrm{D}}-\mathrm{TB}-7$ (Fig. 3). Although there were changes in the nucleotide sequence of the S RNA following passages through the resistant hosts, none were associated solely with the TNDR-breaking phenomenon. This is consistent with the preliminary mapping, indicating that determinants of the ability to overcome resistance are located on TSWV genomic RNAs other than the S RNA.

\section{DISCUSSION}

Heterogeneity and rapid adaptability are two prominent phenotypic characteristics that distinguish TSWV from the majority of plant viruses $(5,36)$. The heterogeneity of the natural viral population provides a potential genetic reservoir for the adaptation of TSWV to a broad range of hosts. In a previous report, we presented evidence for the genome reassortment and the basis of interisolate competition among genome segments (44). We also isolated a resistance-breaking reassortant in the absence of selection pressure. The hypothesis tested in this study was that genome reassortment is one of the genetic mechanisms TSWV utilizes to adapt to resistant plants. To test this hypothesis, we chose TNDR as a model to study the pattern of reassortment of TSWV genomic segments in a defined population in the presence or absence of TNDR. This experimental system, in which the only difference between the resistant plant and the susceptible plant is the presence of the TSWV N gene in the resistant plant genome, permitted us to determine the extent to which the adaptation of the virus might be due to mutation, recombination between the viral genes, recombination with the transgene, or whether reassortment might play a significant role in the adaptation. Constitutive expression of TNDR (Table 1) reduced the possibility that resistance could be overcome by point mutations in the viral genes commonly associated with a failure of induced resistance. Most importantly, this system permitted us to assay the influences of selection by the TSWV-derived $\mathrm{N}$ transgene on the viral population.

The results showed that TNDR could drive the mixed population of TSWV isolates to form a specific reassortant, $\mathrm{L}_{10} \mathrm{M}_{10} \mathrm{~S}_{\mathrm{D}}$. The verification of the reassortment genotypes by two genomic markers on each of the genomic RNAs (Fig. 1) indicated that major recombination events had not occurred. The full-length S RNA sequence from the seventh transfer of the viral population on the N-gene transgenic plants ruled out recombination between the two S RNAs from TSWV-10 and TSWV-D, as well as with the TSWV N transgene. Other TSWV isolates $\left(\mathrm{L}_{10} \mathrm{M}_{\mathrm{D}} \mathrm{S}_{\mathrm{D}}, \mathrm{L}_{\mathrm{D}} \mathrm{M}_{10} \mathrm{~S}_{\mathrm{D}}\right.$, or $\left.\mathrm{L}_{10} \mathrm{M}_{10} \mathrm{~S}_{10}\right)$ were restricted to the local infection on the $\mathrm{N}$-gene transgenic plants, which provided additional circumstantial evidence that point mutations in viral proteins on any individual segments of $\mathrm{L}_{10} \mathrm{M}_{10} \mathrm{~S}_{\mathrm{D}}$ are unlikely to be responsible for breaking TNDR. The results strongly support the hypothesis that TSWV utilizes genomic reassortment as a genetic tool to adapt to the $\mathrm{N}$-gene transgenic plants.

It is significant that most of the heterogeneities introduced by passages on the $\mathrm{N}$-gene transgenic plants were in the NSs ORF.

TABLE 2. The genotype analysis of 120 local lesion isolates randomly selected from the first, fourth, and seventh serial transfers of a mixed viral population initiated with TSWV-D and TSWV-10 isolates coinoculated onto resistant (Ngene transgenic) and susceptible Nicotiana tabacum cv. Burley 21 plants

\begin{tabular}{|c|c|c|c|c|c|c|}
\hline \multirow[b]{3}{*}{ Host plants } & \multicolumn{6}{|c|}{ Serial transfers } \\
\hline & \multicolumn{2}{|l|}{$1 \mathrm{st}$} & \multicolumn{2}{|l|}{4 th } & \multicolumn{2}{|l|}{7 th } \\
\hline & Composition & $\mathrm{No}^{\mathrm{a}}$ & Composition & No. & Composition & No. \\
\hline Resistant $^{\mathrm{b}}$ & $\begin{array}{l}\mathrm{L}_{10} \mathrm{M}_{10} \mathrm{~S}_{\mathrm{D}}{ }^{\mathrm{c}} \\
\mathrm{L}_{10+\mathrm{D}} \mathrm{M}_{10} \mathrm{~S}_{\mathrm{D}} \\
\mathrm{L}_{10+\mathrm{D}} \mathrm{M}_{10} \mathrm{~S}_{\mathrm{D}+10} \\
\mathrm{~L}_{10} \mathrm{M}_{10} \mathrm{~S}_{\mathrm{D}+10}\end{array}$ & $\begin{array}{l}5 \\
5 \\
6 \\
4\end{array}$ & $\begin{array}{l}\mathrm{L}_{10} \mathrm{M}_{10} \mathrm{~S}_{\mathrm{D}} \\
\mathrm{L}_{10+\mathrm{D}} \mathrm{M}_{10} \mathrm{~S}_{\mathrm{D}} \\
\mathrm{L}_{10+\mathrm{D}} \mathrm{M}_{10} \mathrm{~S}_{\mathrm{D}+10} \\
\mathrm{~L}_{10} \mathrm{M}_{10} \mathrm{~S}_{\mathrm{D}+10}\end{array}$ & $\begin{array}{l}8 \\
8 \\
2 \\
2\end{array}$ & $\mathrm{~L}_{10} \mathrm{M}_{10} \mathrm{~S}_{\mathrm{D}}$ & 20 \\
\hline Susceptible $^{b}$ & $\begin{array}{l}\mathrm{L}_{10} \mathrm{M}_{10} \mathrm{~S}_{\mathrm{D}} \\
\mathrm{L}_{10+\mathrm{D}} \mathrm{M}_{10} \mathrm{~S}_{\mathrm{D}} \\
\mathrm{L}_{10+\mathrm{D}} \mathrm{M}_{10} \mathrm{~S}_{\mathrm{D}+10} \\
\mathrm{~L}_{10+\mathrm{D}} \mathrm{M}_{10} \mathrm{~S}_{10} \\
\mathrm{~L}_{10+\mathrm{D}} \mathrm{M}_{10+\mathrm{D}} \mathrm{S}_{\mathrm{D}} \\
\mathrm{L}_{10} \mathrm{M}_{10} \mathrm{~S}_{\mathrm{D}+10}\end{array}$ & $\begin{array}{l}2 \\
7 \\
7 \\
2 \\
1 \\
1\end{array}$ & $\begin{array}{l}\mathrm{L}_{10} \mathrm{M}_{10} \mathrm{~S}_{\mathrm{D}} \\
\mathrm{L}_{10+\mathrm{D}} \mathrm{M}_{10} \mathrm{~S}_{\mathrm{D}} \\
\mathrm{L}_{10+\mathrm{D}} \mathrm{M}_{10} \mathrm{~S}_{\mathrm{D}+10} \\
\mathrm{~L}_{10+\mathrm{D}} \mathrm{M}_{10+\mathrm{D}} \mathrm{S}_{\mathrm{D}}\end{array}$ & $\begin{array}{r}1 \\
10 \\
8 \\
1\end{array}$ & $\begin{array}{l}\mathrm{L}_{10+\mathrm{D}} \mathrm{M}_{10} \mathrm{~S}_{\mathrm{D}} \\
\mathrm{L}_{10+\mathrm{D}} \mathrm{M}_{10} \mathrm{~S}_{\mathrm{D}+10} \\
\mathrm{~L}_{10+\mathrm{D}} \mathrm{M}_{10+\mathrm{D}} \mathrm{S}_{\mathrm{D}+10}\end{array}$ & $\begin{array}{r}14 \\
5 \\
1\end{array}$ \\
\hline
\end{tabular}

a The number of isolates possessing that particular genome composition.

b Resistant: Tomato spotted wilt virus (TSWV) N gene-derived resistant $N$. tabacum cv. Burley 21. Susceptible: N. tabacum cv. Burley 21.

c Subscript refers to the origin of that segment: TSWV-D or TSWV-10. Some isolates contained segments from both parents, e.g., $\mathrm{L}_{10+\mathrm{D}}$. It is not known if this is due to packaging or a mixture of isolates. 
Four amino acid substitutions in the NSs ORF, $\mathrm{P}_{233}$ to $\mathrm{S}, \mathrm{V}_{370}$ to $\mathrm{E}$, $R_{408}$ to $\mathrm{Q}$, and $\mathrm{R}_{450}$ to $\mathrm{G}$, occur in reassortants with the genotype of $\mathrm{L}_{10} \mathrm{M}_{10} \mathrm{~S}_{\mathrm{D}}$ and $\mathrm{L}_{10+\mathrm{D}} \mathrm{M}_{10} \mathrm{~S}_{\mathrm{D}}$ after the coinfection of TSWV-D with TSWV-10. Since the NSs ORF of TSWV-10, which is not involved in the resistance breaking, also has those four amino acids $\left(\mathrm{S}_{233}, \mathrm{E}_{370}, \mathrm{Q}_{408}\right.$, and $\left.\mathrm{G}_{450}\right)$, those amino acid substitutions could not be linked to the resistance breaking. The significance of the unique $\mathrm{T}_{311}$ in the NSs ORF of $\mathrm{L}_{10} \mathrm{M}_{10} \mathrm{~S}_{\mathrm{D}}$ and the unique $\mathrm{D}_{158}$ in the NSs ORF of $\mathrm{L}_{10} \mathrm{M}_{10} \mathrm{~S}_{\mathrm{D}}$-TB-7 in the determination of particular phenotypes needs further investigation.

The mechanism of TNDR is not precisely known. The resistance phenotype is characterized by chlorotic lesions on the inoculated leaf; however, systemic movement of suppressed isolates is inhibited. This would imply that the inserted TSWV $\mathrm{N}$ gene might interfere with the systemic movement. Posttranscriptional transgene silencing has been implicated in the suppression of the invading TSWV genome in transgenic plants (39). The silencing of the transgene transcripts and viral RNAs was proposed to be mediated by the homology-dependent RNA degradation in the cyto- plasm $(4,15,23)$. Viral coat protein-mediated resistance has been postulated to operate by transinactivation of viral replication, virion disassembly and assembly, and interference with host components (4). In addition, a highly specific, inducible resistance in the transgenic plants expressing coat protein was reported for tobacco etch potyvirus (31). In other systems such as replicase-derived resistance, two independent mechanisms, the inhibition of viral replication and the blockage of systemic movement, were reported (25). The $\mathrm{N}$ transgene used for the development of transgenic plants originated from the S RNA of TSWV-D. The TNDR-breaking reassortant, $\mathrm{L}_{10} \mathrm{M}_{10} \mathrm{~S}_{\mathrm{D}}$, also had the S RNA from TSWV-D. Therefore, TNDR in our investigation may not meet the rigorous conditions of the homology-dependent RNA degradation model (4), but is more likely explained by a modification of the model which also accommodates a blockage of systemic movement.

The specific selection per se is unable to cause genome reassortment. The reassortment of the RNAs from two suppressed isolates under TNDR selection to form a specific combination, which is capable of defeating the resistance in the absence of any con-
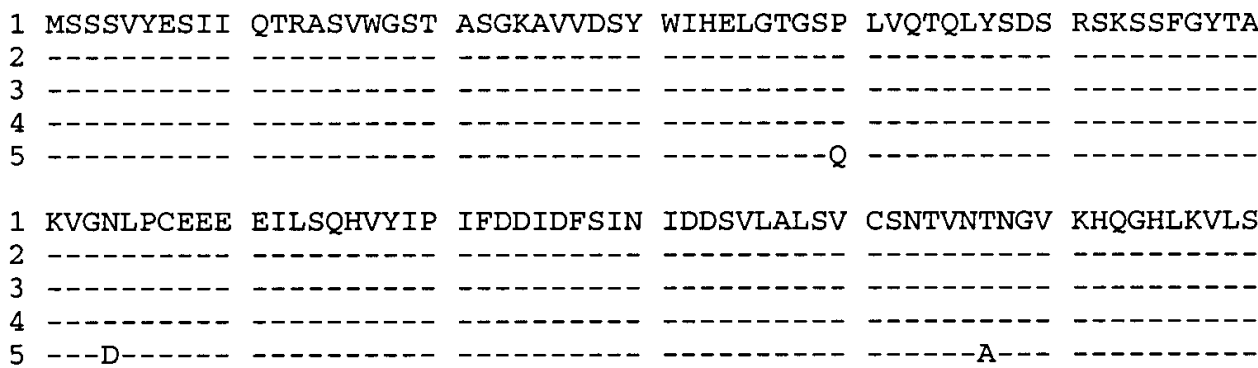

1 PAQLHSIGST MNRSDITDRF QLQEKDIIPN DRYIEAANKG SLSCVKEHTY KIEMCYNQAL 180

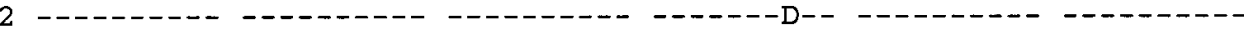

3 -

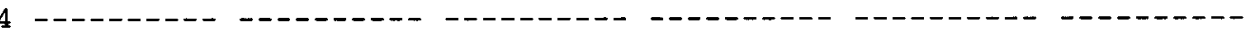

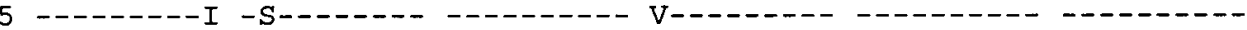

1 GKVNVLSPNR NVHEWLYSFK PSFNQVESNN RTVNSLAVKS LLMSAENNIM PNSQAFVKAS 240

2 -

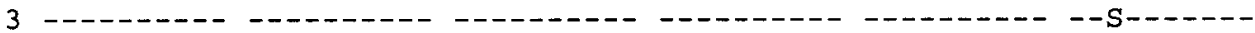

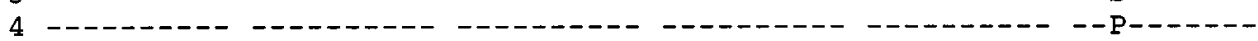

5 -

1 TDSHFKLSLW LRVPKVLKQV SIQKLFKVAG DETNKTFYLS IACIPNHNSV ETALNISVIC 300

3 -

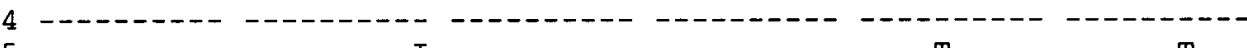

5 - - - - - - - - - - -

1 KHQLPIRKCK TPFELSMMFS DLKEPYNIVH DPSYPQRIVH ALLETHTSFA QVLCNNLQED 360

2 -

3 -

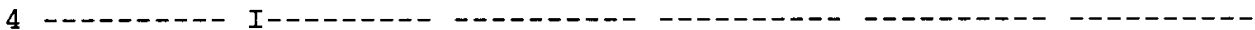

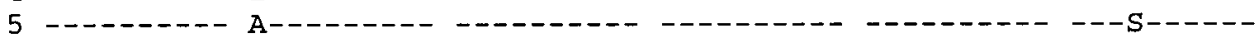

1 VIIYTLNNYE LTPGKLDLGE RTLNYSEDIC KRKYFLSKTL ECLPSNTQTM SYLDSIQIPS 420

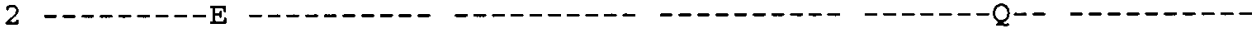

3 - - - - K-E --

4 - - - - - - $-\mathrm{V}$ - - - - - - - - - -

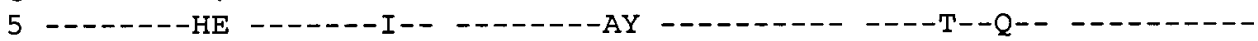

1 WKIDFARGEI KISPQPVSVA KSLLKLDLSG IEKKESKIPE TYASGSK 467

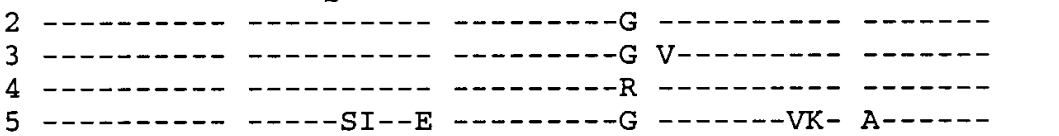

Fig. 3. The predicted NSs amino acid sequence comparison of TSWV-D, TSWV-10, reassortant $\mathrm{L}_{10} \mathrm{M}_{10} \mathrm{~S}_{\mathrm{D}}-\mathrm{TB}-7$ (from the seventh transfer of viral population on the TSWV N gene-derived resistance [TNDR] Nicotiana tabacum cv. Burley 21), $\mathrm{L}_{10+\mathrm{D}} \mathrm{M}_{10} \mathrm{~S}_{\mathrm{D}}-\mathrm{B}-7$ (from the seventh transfer of viral population on the susceptible $N$. tabacum cv. Burley 21), and $\mathrm{L}_{10} \mathrm{M}_{10} \mathrm{~S}_{\mathrm{D}}$ (from the mixed infection of TSWV-D and TSWV-10 on the susceptible N. tabacum cv. Burley 21). Rows 1, TNDR-breaking reassortant $\mathrm{L}_{10} \mathrm{M}_{10} \mathrm{~S}_{\mathrm{D}}$ isolated from the susceptible $N$. tabacum cv. Burley 21; rows $2, \mathrm{~L}_{10} \mathrm{M}_{10} \mathrm{~S}_{\mathrm{D}}-\mathrm{TB}-7 ;$ rows 3, $\mathrm{L}_{10+\mathrm{D}} \mathrm{M}_{10} \mathrm{~S}_{\mathrm{D}}-\mathrm{B}-7$; rows 4 , TSWV-D; and rows 5, TSWV-10. Identical amino acids are indicated by dashes. 
comitant alteration in the $\mathrm{N}$ gene, provides support for the hypothesis that overcoming TNDR is a cooperative event involving two or more elements. It is probable that the capacity of the reassortant $\mathrm{L}_{10} \mathrm{M}_{10} \mathrm{~S}_{\mathrm{D}}$ to break TNDR results from the concerted interaction among viral proteins resident on separate viral RNAs contributed by each of the original viruses. That neither parent alone is capable of overcoming TNDR is further support of this hypothesis. The resistance may be broken directly by the cooperative effect of viral proteins that permits systemic movement or by the suppression of the resistance response such as has been proposed for suppression of posttranslational transgene silencing $(3,6,26)$.

Preliminary genetic mapping of the determinants of the resistance-breaking phenotype and of systemic movement (44) also supports the involvement of genome segments other than the $S$ RNA. The mechanism of driving the reassortment of the genome RNAs into an "adapted" combination could include the preferential selection of segments by the resistant hosts or that the RNAs from one parental isolate versus the corresponding RNAs from the other parental isolate are preferentially acceptable template for the RdRp. Thus, an equally significant question is does the host influence the RdRp complex of TSWV to favor one template over the other in response to the selection? A previous observation suggested that the S RNA from TSWV-D was more competitive than the corresponding S RNA from TSWV-10 (44) and the individual RNAs rather than the overall genome was specifically selected in response to the selection (Fig. 2 and Table 2). Although details of how the RdRp complex actively interacts with their templates have not been elucidated, these observations suggest the possible role of the viral RdRp complex in the genetic reassortment.

The possibility of generating new viruses on the viral pathogenderived resistant plants is still controversial $(16,34,45)$. In this study, the tendency of TNDR to drive the mixed viral population to form a novel resistance-breaking isolate (Fig. 2 and Table 2) supports the speculation that the potential risk of generating a new virus exists on the transgenic plant as it does with the natural, hostderived resistance. It is known that new TSWV isolates can be generated on host-derived resistant plants $(7,41)$. The emergence of the novel isolate results from the genome reassortment indirectly influenced by TNDR rather than from the direct rearrangement between the viral genome and the transgene, which provides evidence for an additional mechanism for adaptation of plant viruses $(19,24,32,47)$. Mixed infections of various TSWV isolates occur commonly on host plants, as evidenced by the existence of heterogeneous populations in the field $(5,9,10,37,48,51,53 ; \mathrm{J}$. W. Moyer, unpublished data). Therefore, the opportunities for TSWV isolates to adapt to new host genotypes are greatly increased. Since resistant plants have the potential to drive viral populations to generate a resistance breaking isolate(s), we suggest that transgenic plants should be assessed using mixed infections of genetically compatible isolates to test the efficiency of resistance and to predict the possibility of inducing new isolates.

\section{ACKNOWLEDGMENTS}

We thank F. Gould, S. A. Lommel, G. A. Payne, K.-B. G. Scholthof, and H. B. Scholthof for their critical comments. We also thank J. Speck, J. Abad, and K. Hoffmann for their technical assistance and helpful discussion.

\section{LITERATURE CITED}

1. Adkins, S., Choi, T.-J., Israel, B. A., Bandla, M. D., Richmond, K. E., Schultz, K. T., Sherwood, J. L., and German, T. L. 1996. Baculovirus expression and processing of tomato spotted wilt tospovirus glycoproteins. Phytopathology 86:849-855.

2. Adkins, S., Quadt, R., Choi, T., Ahlquist, P., and German, T. L. 1995. An RNA-dependent RNA polymerase activity associated with virions of tomato spotted wilt virus, a plant- and insect- infecting Bunyavirus. Virology 207:308-311.

3. Anandalakshmi, R., Pruss, G. J., Ge, X., Marathe, R., Mallory, A. C., Smith, T. H., and Vance, V. B. 1998. A viral suppressor of gene silencing in plants. Proc. Natl. Acad. Sci. U.S.A. 95:13079-13084.

4. Baulcombe, D. C. 1996. Mechanisms of pathogen-derived resistance to viruses in transgenic plants. Plant Cell 8:1833-1844.

5. Best, R. J. 1968. Tomato spotted wilt virus. Pages 65-145 in: Advances in Virus Research. K. M. Smith and M. A. Lauffer, eds. Academic Press, New York.

6. Brigneti, G., Voinnet, O., Li, W. X., Ji, L. H., Ding, S. W., and Baulcombe, D. C. 1998. Viral pathogenicity determinants are suppressors of transgene silencing in Nicotiana benthamiana. EMBO (Eur. Mol. Biol. Organ.) J. 17:6739-6746.

7. Cho, J. J., Custer, D. M., Brommonnschenkel, S. H., and Tanksley, S. D. 1996. Conventional breeding: Host-plant resistance and the use of molecular markers to develop resistance to tomato spotted wilt virus in vegetables. Acta Hortic. 431:367-378.

8. Daub, M. E., Jones, R. K., and Moyer, J. W. 1996. Biotechnological approaches for virus resistance in floral crops. Pages 335-351 in: Biotechnology of Ornamental Plants. R. L. Geneve, J. E. Preece, and S. A. Merkle, eds. CAB International, Wallingford, United Kingdom.

9. de Avila, A. C., de Haan, P., Kormelink, R., Resende, R. D. O., Goldbach, R. W., and Peters, D. 1993. Characterization of tospoviruses based on phylogeny of nucleoprotein gene sequences. J. Gen. Virol. 74:153-159.

10. de Avila, A. C., Huguenot, C., Resende, R. D. O., Kitajima, E. W., Goldbach, R. W., and Peters, D. 1990. Serological differentiation of 20 isolates of tomato spotted wilt virus. J. Gen. Virol. 71:2801-2807.

11. de Haan, P., Gielen, J. J. L., Prins, M., Wijkamp, I. G., van Schepen, A., Peters, D., van Grinsven, M. Q. J. M., and Goldbach, R. 1992. Characterization of RNA-mediated resistance to tomato spotted wilt virus in transgenic tobacco plants. Bio/Technology 10:1133-1137.

12. de Haan, P., Kormelink, R., Resende, R. D. O., van Poelwijk, F., Peters, D., and Goldbach, R. 1991. Tomato spotted wilt virus L RNA encodes a putative RNA polymerase. J. Gen. Virol. 71:2207-2216.

13. de Haan, P., Wagemakers, L., Peters, D., and Goldbach, R. 1990. The S RNA segment of tomato spotted wilt virus has an ambisense character. J. Gen. Virol. 71:1001-1007.

14. Elliott, R. M. 1996. The Bunyaviridae: Concluding remarks and future prospects. Pages 295-332 in: The Bunyaviridae. R. M. Elliott, ed. Plenum Press, New York.

15. English, J. J., Mueller, E., and Baulcombe, D. C. 1996. Suppression of virus accumulation in transgenic plants exhibiting silencing of nuclear genes. Plant Cell 8:179-188.

16. Falk, B. W., and Bruening, G. 1994. Will transgenic crops generate new viruses and new diseases? Science 263:1395-1396.

17. Finlay, K. W. 1952. Inheritance of spotted wilt resistance in the tomato. I. Identification of strains of the virus by the resistance or susceptibility of tomato species. Aust. J. Sci. Res. 5:303-314.

18. Finlay, K. W. 1953. Inheritance of spotted wilt resistance in the tomato. II. Five genes controlling spotted wilt resistance in four tomato types. Aust. J. Biol. Sci. 6:153-163.

19. Gal, S., Pisan, B., Hohn, T., Grimsley, N., and Hohn, B. 1992. Agroinfection of transgenic plants leads to viable cauliflower mosaic virus by intermolecular recombination. Virology 187:525-533.

20. German, T. L., Ullman, D. E., and Moyer, J. W. 1992. Tospoviruses: Diagnosis, molecular biology, phylogeny, and vector relationships. Annu. Rev. Phytopathol. 30:315-348.

21. Gielen, J. J. L., de Haan, P., Kool, A. J., Peters, D., van Grinsven, M. Q. J. M., and Goldbach, R. 1991. Engineered resistance to tomato spotted wilt virus, a negative-strand RNA virus. Bio/Technology 9:1363-1367.

22. Goldbach, R., and Peters, D. 1996. Molecular and biological aspects of tospoviruses. Pages 129-157 in: The Bunyaviridae. R. M. Elliott, ed. Plenum Press, New York.

23. Goodwin, J., Chapman, K., Swaney, S., Parks, T. D., Wernsman, E. A., and Dougherty, W. G. 1996. Genetic and biochemical dissection of transgenic RNA-mediated virus resistance. Plant Cell 8:95-105.

24. Greene, A. E., and Allison, R. F. 1994. Recombination between viral RNA and transgenic plant transcripts. Science 263:1423-1435.

25. Hellwald, K., and Palukaitis, P. 1995. Viral RNA as a potential target for two independent mechanisms of replicase-mediated resistance against cucumber mosaic virus. Cell 83:937-946.

26. Kasschau, K. D., and Carrington, J. C. 1998. A counterdefensive strategy of plant viruses: Suppression of posttranscriptional gene silencing. Cell 95:461-470.

27. Kim, J. W., Sun, S. S. M., and German, T. L. 1994. Disease resistance in tobacco and tomato plants transformed with the tomato spotted wilt virus nucleocapsid gene. Plant Dis. 78:615-621.

28. Kormelink, R., de Hann, P., Meurs, C., Peters, D., and Goldbach, R. 1992. The nucleotide sequence of the M RNA segment of tomato spotted wilt virus, a Bunyavirus with two ambisense RNA segments. J. Gen. Virol. 73:2795-2804.

29. Law, M. D., and Moyer, J. W. 1990. A tomato spotted wilt-like virus 
with a serologically distinct N protein. J. Gen. Virol. 71:933-938.

30. Law, M. D., Speck, J., and Moyer, J. W. 1992. The M RNA of impatiens necrotic spot Tospovirus (Bunyaviridae) has an ambisense genomic organization. Virology 188:732-741.

31. Lindbo, J. A., Silva-Rosales, L., Proebsting, W. M., and Dougherty, W. G. 1993. Induction of a highly specific antiviral state in transgenic plants: Implications for regulation of gene expression and virus resistance. Plant Cell 5:1749-1759.

32. Lommel, S. A., and Xiong, Z. 1991. Reconstitution of a functional red clover necrotic mosaic virus by recombinational rescue of the cell-to-cell movement gene expressed in a transgenic plant. J. Cell. Biochem. 15A:151.

33. MacKenzie, D. J., and Ellis, P. J. 1992. Resistance to tomato spotted wilt virus infection in transgenic tobacco expressing the viral nucleocapsid gene. Mol. Plant-Microbe Interact. 5:34-40.

34. Miller, W. A., Koev, G., and Mohan, B. R. 1997. Are there risks associated with transgenic resistance to Luteoviruses? Plant Dis. 81:700-710.

35. Moyer, J. W., and Cali, B. B. 1985. Properties of sweet potato feathery mottle virus RNA and capsid protein. J. Gen. Virol. 66:1185-1189.

36. Moyer, J. W., and Qiu, W. P. 1996. Molecular and genetic determinants of diversity in tomato spotted wilt virus. Acta Hortic. 431:219-227.

37. Norris, D. O. 1946. The strain complex and symptom variability of spotted wilt virus. Bull. Aust. Counc. Sci. Ind. Res. 202.

38. Pang, S.-Z., Bock, J. H., Gonsalves, C., Slightom, J. L., and Gonsalves, D. 1994. Resistance of transgenic Nicotiana benthamiana plants to tomato spotted wilt and impatiens necrotic spot tospoviruses: Evidence of involvement of the $\mathrm{N}$ protein and $\mathrm{N}$ gene RNA in resistance. Phytopathology 84:243-249.

39. Pang, S.-Z., Jan, F. J., Carney, K., Stout, J., Tricoli, D. M., Quemada, H. D., and Gonsalves, D. 1996. Post-transcriptional transgene silencing and consequent tospovirus resistance in transgenic lettuce are affected by transgene dosage and plant development. Plant J. 9:899-909.

40. Pang, S.-Z., Jan, F.-J., and Gonsalves, D. 1997. Nontarget DNA sequences reduce the transgene length necessary for RNA-mediated tospovirus resistance in transgenic plants. Proc. Natl. Acad. Sci. U.S.A. 94:8261-8266.

41. Paterson, R. G., Scott, S. J., and Gergerich, R. C. 1989. Resistance in two Lycopersicon species to an Arkansas isolate of tomato spotted wilt virus. Euphytica 43:173-178.

42. Perez, R., Geske, S. M., Speck, J., Reece, P., Moyer, J. W., and Daub, M.
E. 1993. Transformation of tobacco with four different nucleocapsid constructs of tomato spotted wilt virus. (Abstr.) Phytopathology 83:1355.

43. Prins, M., Kikkert, M., Ismayadi, C., de Graauw, W., de Hann, P., and Goldbach, R. 1997. Characterization of RNA-mediated resistance to tomato spotted wilt virus in transgenic tobacco plants expressing NSm gene sequences. Plant Mol. Biol. 33:235-243.

44. Qiu, W. P., Geske, S. M., Hickey, C. M., and Moyer, J. W. 1998. Tomato spotted wilt Tospovirus genome reassortment and genome segment-specific adaptation. Virology 244:186-194.

45. Roossinck, M. J. 1997. Mechanisms of plant virus evolution. Annu. Rev. Phytopathol. 35:191-209.

46. Sanger, F., Nicklen, S., and Coulson, A. R. 1977. DNA sequencing with chain-termination inhibitors. Proc. Natl. Acad. Sci. U.S.A. 74:5463-5467.

47. Schoelz, J. E., and Wintermantel, W. M. 1993. Expansion of viral host range through complementation and recombination in transgenic plants. Plant Cell 5:1669-1679.

48. Sherwood, J. L., Sanborn, M. R., Keyer, G. C., and Myer, L. D. 1989. Use of monoclonal antibodies in detection of tomato spotted wilt virus. Phytopathology 79:61-64.

49. Stevens, M. R., Scott, S. J., and Gergerich, R. C. 1992. Inheritance of a gene for resistance to tomato spotted wilt virus (TSWV) from Lycopersicon peruvianum Mill. Euphytica 59:9-17.

50. Storms, M. M. H., Kormelink, R., Peters, D., VanLent, J. W. M., and Goldbach, R. W. 1995. The nonstructural NSm protein of tomato spotted wilt virus induces tubular structures in plant and insect cells. Virology 214:485-493.

51. Tsakiridis, J. P., and Gooding, G. V. 1972. Tomato spotted wilt virus in Greece. Phytopathol. Mediterr. 11:42-47.

52. Vaira, A. M., Semeria, L., Crespi, S., Lisa, V., Allavena, A., and Accotto, G. P. 1995. Resistance to tospoviruses in Nicotiana benthamiana transformed with the $\mathrm{N}$ gene of tomato spotted wilt virus: Correlation between transgene expression and protection in primary transformants. Mol. Plant-Microbe Interact. 8:66-73.

53. Wang, M., and Gonsalves, D. 1990. ELISA detection of various tomato spotted wilt virus isolates using specific antisera to structural proteins of the virus. Plant Dis. 74:154-158.

54. Weng, Z., and Xiong, Z. 1995. A method for accurate determination of terminal sequences of viral genomic RNA. Genome Res. 5:202-207. 